\title{
New SHRIMP Age and Microstructures from a Deformed A-Type Granite, Kanigiri, Southern India: Constraining the Hiatus between Orogenic Closure and Postorogenic Rifting
}

\author{
Arnab Sain, ${ }^{1}$ Dilip Saha, ${ }^{1, \star}$ Sojen Joy, ${ }^{2}$ Hielke Jelsma, ${ }^{3}$ and Richard Armstrong ${ }^{4}$ \\ 1. Geological Studies Unit, Indian Statistical Institute, Kolkata 700108, India; 2. De Beers Group, Johannesburg, \\ South Africa; 3. Anglo American Exploration, 45 Main Street, Johannesburg, South Africa; 4. Research \\ School of Earth Sciences, Australian National University, Canberra, Australia
}

\begin{abstract}
A B S T R A C T
A new U-Pb zircon SHRIMP age of $1284 \mathrm{Ma}$ from the Kanigiri granite, India, is reported to help constrain the middle to late Mesoproterozoic tectonic evolution of the Nellore schist belt (NSB). The Kanigiri granite has whole-rock chemical characteristics of A-type granites and is marked by light rare earth element enrichment, a strong negative Eu anomaly, and negative $\mathrm{Ba}, \mathrm{Sr}, \mathrm{P}, \mathrm{Ti}$, and $\mathrm{Yb}$ anomalies, indicating feldspar, apatite, and ilmenite/magnetite fractionation. Samples show $\mathrm{Y} / \mathrm{Nb}$ versus $\mathrm{Yb} / \mathrm{Ta}$ ratios in the range for granites associated with ocean island basalts. This two-mica granite is peraluminous and alkali-calcic to calc-alkalic, and it has high annite to phlogopite proportions $(92 \%-98 \%)$. Strong alignment of flattened mafic microgranular enclaves in the granite, together with relatively high- to moderate-temperature crystal plastic deformation fabric in shear zones within the granite, suggest overprinting of subsolidus deformation over a relict magmatic fabric, a feature not very common in true anorogenic granites but reported in late- to postorogenic granites elsewhere. An intrusive relationship with the 1334 Ma Kanigiri ophiolitic mélange, within the NSB, indicates that there is a $\leq 50 \mathrm{~m}$.yr. gap between the Mesoproterozoic subduction-accretion, represented by the ophiolite mélange and late- to postorogenic granite emplacement. Although the Kanigiri granite occurs in close proximity to mafic and felsic alkaline plutons belonging to the 1250-1400 Ma Prakasam alkaline province (PAkP) in the northern NSB and there is overlap in age, the Atype granitic magma source is apparently unrelated to PAkP alkaline magmatism. Our work further substantiates the observation that A-type granites originate in varied tectonic settings, not necessarily only in a rift-related (intraplate) setting.
\end{abstract}

Online enhancements: appendix, supplemental tables.

\section{Introduction}

Granitic rocks show huge diversity in their mineralogy, geochemistry, and structural features because of (1) the wide variation in sources and magmatic processes, (2) emplacement at different crustal levels and under different tectonic settings and geodynamic conditions, and (3) subsequent tectonic evolutionary history (e.g., Barbarian 1999). While the more common I-, M-, and S-type granites have been defined on the basis of their interpreted protoliths (igneous, mantle, and sedimentary, respectively; Chappel and White 1974; White 1979|, A-type granitoids have been proposed to be anorogenic or anhydrous (Loiselle and Wones 1979), emphasizing their tectonic setting as

Manuscript received May 27, 2016; accepted October 26, 2016; electronically published February 7, 2017

* Author for correspondence; e-mail: dsaha@isical.ac.in. well as source magmas with limited $\mathrm{H}_{2} \mathrm{O}$. Since similar granitic composition can result from partial melting of a variety of sources, some authors prefer a classification scheme based on geochemistry alone (e.g., Frost et al. 2001). Chemically, the A-type granites are characterized by their relatively high alkali content (at $\mathrm{SiO}_{2}=70 \% ; \mathrm{Na}_{2} \mathrm{O}+\mathrm{K}_{2} \mathrm{O}=7 \%-11 \%$ ), low $\mathrm{CaO}$ content $(\mathrm{CaO}<1.8 \%)$, $\mathrm{FeO}^{\mathrm{T}} / \mathrm{MgO}$ ratios of $8-80$ (at $\mathrm{SiO}_{2}=70 \%$, and often elevated halogen content, particularly $\mathrm{F}(\mathrm{F}=0.05 \%-1.7 \%$; Eby 1990$)$. They can be emplaced in rift (within plate) or late- to postcollisional settings (Eby 1992). In Precambrian terrains with multiple orogenic imprints, the recognition of apparent A-type granites and the understanding of the origin and tectonic setting is inherently more complex because of postemplacement modification due to deformation and metamorphic/metasomatic 
changes. A related issue is how to distinguish between postcollisional plutons with reference to a known orogenic event and truly continental rift-related felsic plutons formed after complete cessation of orogenic activity in a polydeformed and polymetamorphosed terrain.

In southern India, A-type granites, reported from the central part of the late Archean-Proterozoic Nellore schist belt (NSB), are often grouped with spatially related mafic to felsic alkaline plutons constituting the so-called Prakasam alkaline province (PAkP; fig. 1; Leelanandam 1989; Ratnakar and Leelanandam 1989). On the basis of supposed connections between rifting and alkaline magmatism and reported deformation in some of the PAkP plutons, a case has been made for lithospheric extension, ocean opening, and subsequent closure affecting the eastern margin of the Dharwar craton, India (Leelanandam et al. 2006). While the available dates indicate that the main PAkP plutons, like Elchuru, Purimetla, and Uppalapadu, were formed during the interval 1250-1400 Ma (Upadhyaya 2008), there are spatially close granitic plutons like the Kanigiri granite that are not strictly alkaline (e.g., Sesha Sai 2013), and their emplacement ages are to date not well constrained (cf. Gupta et al. 1984).

The NSB is known to be a heterogeneous ensemble consisting of four distinct tectonostratigraphic units with distinct geochemical attributes that were episodically accreted to the Dharwar craton margin over a prolonged period of time since the Neoarchean (Ravikant 2010; Saha et al. 2015). Two small ophiolitic domains - namely, the ca. 1900 Ma Kandra ophiolite complex (KOC) and the ca. $1334 \mathrm{Ma}$ Kanigiri ophiolitic mélange (KOM) — occurring within the NSB also indicate repeated subduction-related tectonic convergence along the eastern margin of Proterozoic southern India (Saha 2004, 2011; Vijaya Kumar et al. 2010; Dharma Rao et al. 2011; Saha et al. 2015). Dharma Rao and Reddy (2007) described the geochemistry of the Kanigiri granite, but there is very little documentation of contact relations with the surrounding rocks of the NSB, including the nearby ophiolitic mélange (KOM), the internal fabric of the pluton, or deformation microstructures and their relationship with the regional deformation phases. We revisit the Kanigiri granite intrusion with emphasis on field relations with the country rocks of the NSB, internal fabric, petrographic variation, and deformation microstructures, which are important in understanding the emplacement of the pluton and subsequent tectonic history. In addition, we provide here a new zircon U-Pb SHRIMP age for the Kanigiri pluton. A review of the geochemistry of the Kanigiri pluton based on the published data and data newly obtained during the course of the present work is also presented to help constrain the tectonic setting in the context of Mesoproterozoic subduction-related ophiolite emplacement in the belt and subsequent tectonic hiatus and rejuvenation.

\section{Geological Framework}

The north-south-elongated NSB, an arcuate belt roughly parallel to the southeastern coast of India, is bounded by the Proterozoic Nallamalai fold belt (NFB) to the west and the Eastern Ghats granulite belt (EGB) to the east (fig. 1). Constituent tectonostratigraphic units within the NSB show ages ranging broadly between 3.0 and $0.8 \mathrm{Ga}$ (Ghosh et al. 1994; Ravikant 2010). Geologically and geochemically distinct metamorphosed volcano-sedimentary successions - namely, the Upper Udaygiri Group (western domain) and the Lower Vinjamuru Group (eastern domain) — constitute the bulk of the belt (Ramam and Murty 1997; Dobmeier and Raith 2003; Saha et al. 2015). The Udaygiri Group consists dominantly of metasedimentary rocks with minor intercalations of amygdaloidal/vesicular metabasalt in the lower part. The metasedimentary succession includes feldspathic grits, tuffaceous mudstones, and slates and cross-bedded quartzites, metamorphosed under low greenschist facies condition (Das et al. 2015; Saha et al. 2015).

The Vinjamuru Group in turn consists of massive to amygdaloidal metabasalt intercalated with very thin felsic metatuff horizons, thin quartzite lenses (locally ferruginous), and garnet-staurolite-kyanitebearing pelitic schists. The rocks underwent amphibolite facies metamorphism (Moeen 1998) with local migmatization manifest by intercalated mafic schists and migmatitic gneisses. Late pegmatite veins and stocks also cut across the Vinjamuru Group rocks.

Among the ophiolite remnants, the 1900 Ma KOC occurs in the southern part of the NSB, with imbricate thrust slices documented around Kandra and Gurramkonda hosting hornblende metagabbros, thick massive to pillowed metabasalts, sheeted metadolerite dikes, and thin metapelite and metapsammite horizons intercalated with metabasalt (Sesha Sai 2009; Vijaya Kumar et al. 2010; Saha 2011). On the basis of detailed geochemistry and a lithological association similar to that of deformed remnants of ocean plate stratigraphy, the KOC is interpreted as an oceanic backarc subtype of subduction-related ophiolite (Saha 2011; Saha et al. 2015). The 1334 Ma KOM occurs in the northern part of the NSB and forms a narrow and steeply oriented north-south belt between Podile and Kanigiri, straddling the Vinjamuru and Udaygiri domains (fig. 2; Dharma Rao et al. 2011). The KOM has a heterogeneous assemblage of metabasalts, mafic to 


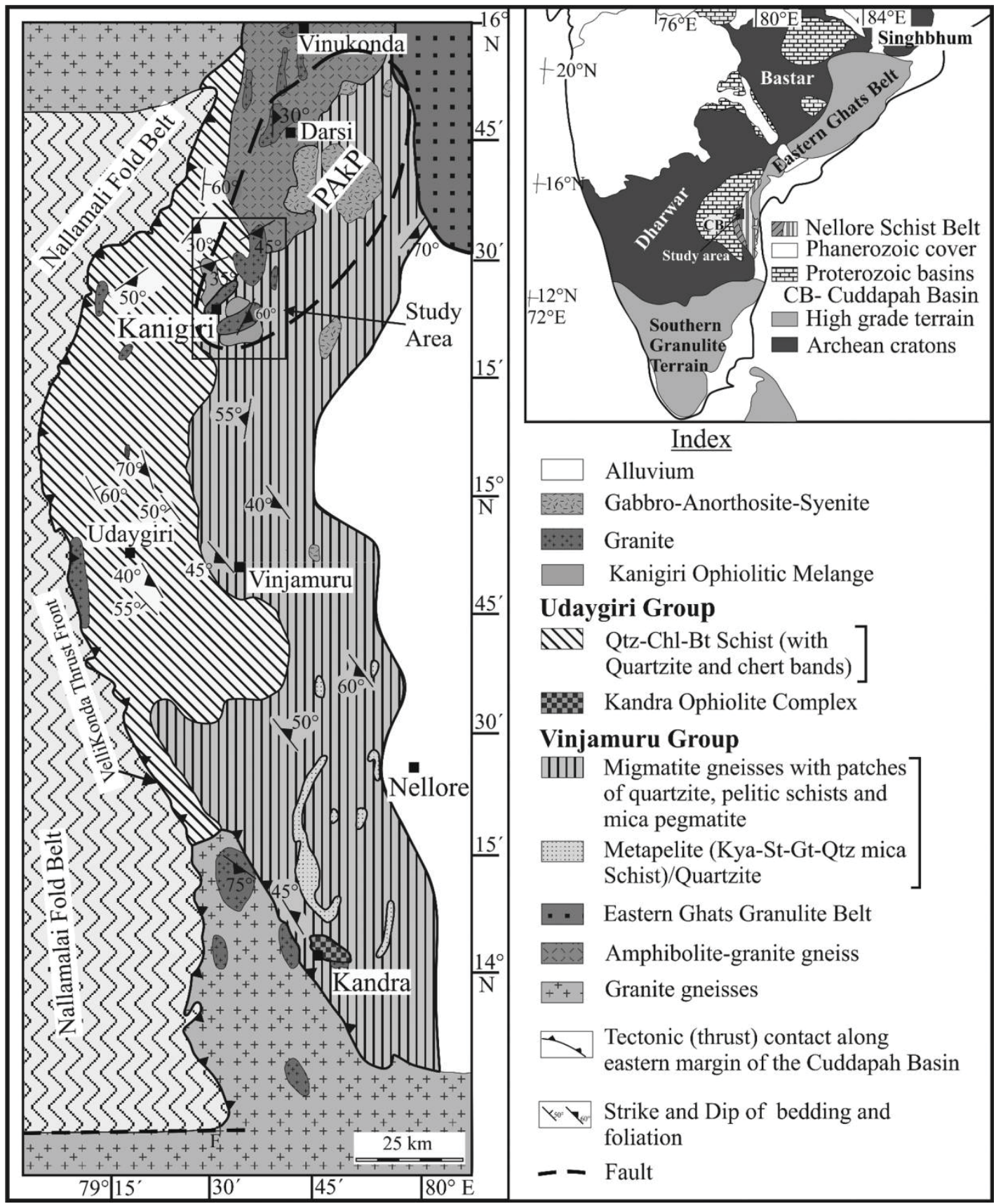

Figure 1. Geological map of the Nellore schist belt and location of the study area, after Srinivasan and Roop Kumar (1995) and Sesha Sai (2013). The extent of the Prakasam alkaline province (PAkP) is shown by the dashed line. A color version of this figure is available online.

felsic metatuffs, agglomerates, and minor metapsammite units, with discontinuous patches of interstratified metacherts and impure marble, and meter- to decameter-sized metagabbro and meta-anorthosite blocks, indicative of a tectonic mélange (Saha et al. 2015). The Kanigiri granite pluton intrudes the KOM, as evidenced by common granitic veins cutting KOM strata near the contact or by the presence of meta- 


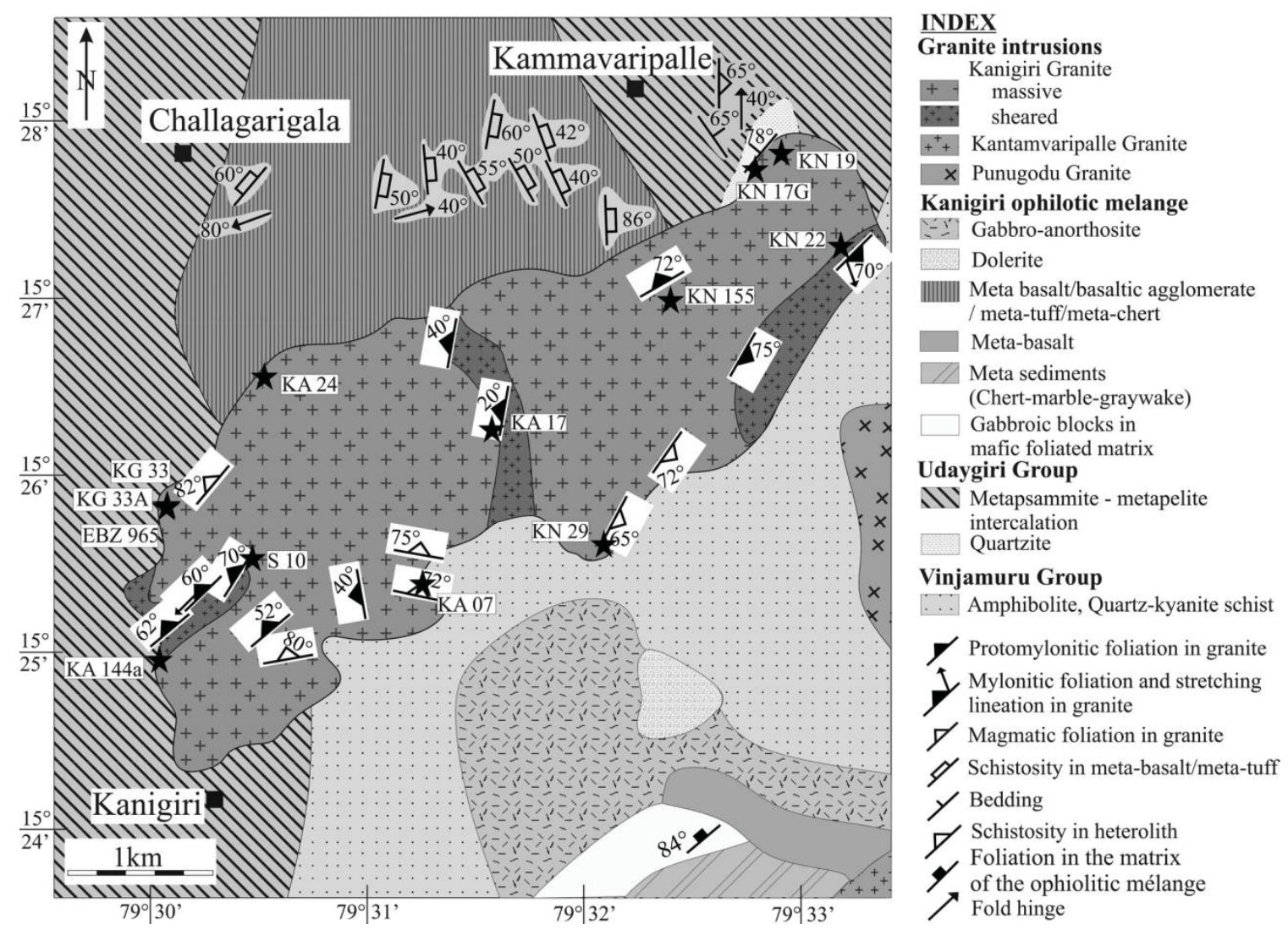

Figure 2. Geological map of the Kanigiri granite and surrounding area with structural data. Stars indicate sample locations. A color version of this figure is available online.

sedimentary and mafic enclaves within the granite intrusion.

A number of alkaline complexes occur in the northern part of the NSB, to the west of the boundary between the Vinjamuru Group and the EGGB, and have commonly been described as the PAkP (Leelanandam 1989). The designated PAkP tract includes alkaline mafic (gabbro-anorthosite) and felsic (syenite, alkali granite) plutons as well as some granitic bodies. Some of the plutons, such as the Elchuru syenite, are emplaced within the Vinjamuru Group rocks (Leelanandam 1989; Ratnakar and Vijay Kumar 1995; Krishna Reddy et al. 1998). Other, nearby felsic plutons, like those at Podile and Kanigiri, directly intrude the KOM rocks located near the contact between the Vinjamuru and Udaygiri domains (fig. 1). The PAkP plutons have been interpreted as Mesoproterozoic rift-related magmatic products, and the deformation recorded in these plutons has been ascribed to later crustal convergence (e.g., Leelanandam et al. 2006). More recent zircon U-Pb dating yielded a more restricted range of emplacement ages bracketed between 1480 and $1262 \mathrm{Ma}$ (Upadhyay 2008).

The Proterozoic felsic magmatism and older deformation in the Vinjamuru domain are constrained by the age of the intrusive Vinukonda granite occurring in the northern NSB (fig. 1). The Vinukonda granite yielded upper-intercept $\mathrm{U}-\mathrm{Pb}$ zircon ages of $1588 \pm 7$ and $1589 \pm 6 \mathrm{Ma}$, interpreted to date magma emplacement (Dobmeier et al. 2006) and regional D2 deformation (Saha et al. 2010). Upadhyay et al. (2006) obtained a U-Pb zircon age of $1321 \pm$ $17 \mathrm{Ma}$ for the Elchuru complex, belonging to the PAkP. Although the Kanigiri granite occurs in the southern part of the PAkP, the emplacement age of the Kanigiri granite is yet to be ascertained.

The Kanigiri granitic pluton cuts across the KOM and is described as A-type granite by Dharma Rao and Reddy (2007). Comparing the geochemistry of the Kanigiri granite and the Podile alkali granite/ syenite body, Sesha Sai (2013) commented that the low $\mathrm{Na}_{2} \mathrm{O} / \mathrm{K}_{2} \mathrm{O}$ ratio $(0.69-0.77)$, the absence of am- 
phibole, the presence of muscovite, and the relatively high A/CNK ratio (1.28-1.31) in the Kanigiri granite are indicative of a sedimentary source, whereas the bulk chemistry of the Podile alkaline granite/syenite indicates an igneous origin. In terms of tectonic setting, the overall geochemical characteristics of the granites emplaced in the NSB have been interpreted in terms of a late-orogenic to anorogenic nature, although the geochemical discrimination plots are not always unambiguous (Sesha Sai 2013).

\section{Regional Deformation}

The EGB represents the main focus of regional highgrade metamorphism and deformation along the southeastern margins of the Dharwar and Bastar cratons in India (fig. 1). The NSB, occurring to the west of the southern EGB along a tectonic contact, is a polymetamorphosed and polydeformed terrain with amalgamation of different tectonostratigraphic units over a prolonged period of time in the Proterozoic (Saha et al. 2015). The NSB, in turn, is thrust over the NFB, representing the eastern margin of the Proterozoic Cuddapah basin, along the Vellikonda thrust front (Venkatakrishnan and Dottiwala 1987). The northern EGB recorded several tectonothermal events, as evidenced by Rb-Sr, Sm-Nd, and SHRIMP ages with clusters around 1600-1500, 1000900, and 600-500 Ma (e.g., Shaw et al. 1997; Rickers et al. 2001; Simmat and Raith 2008). Only the Paleoproterozoic events are reported from the southern EGB (Ongole domain) bordering the NSB (Henderson et al. 2014). Repeated subduction-accretion along the eastern Dharwar craton margin is also evidenced by the ca. $1900 \mathrm{Ma}$ KOC in the southern NSB and the $1334 \mathrm{Ma}$ KOM. Some authors have suggested that arc-continent collision in the region continued until ca. $1000 \mathrm{Ma}$, during the final stages of the amalgamation of the Columbia-derived fragments within the Neoproterozoic supercontinent assembly (Dharma Rao et al. 2011; Santosh 2012).

The structures in the contact zone between the Udaygiri and Vinjamuru domains in the NSB have been interpreted in terms of oblique transpression partitioned into a west-directed thrust and a sinistral strike-slip component (Saha et al. 2011). In the Vinjamuru-Udaygiri sector, three phases of deformation have been recognized (Saha 2004). In the adjoining northern NFB, one can recognize three distinct phases of deformation (D1, D2, and D3; Saha 2002; Tripathy and Saha 2010). The exact date of the D1 deformation in the region, as reflected in the early folds within the NSB and NFB as well as ductile thrusting, is still uncertain. But age constraints on the amalgamation of the Kandra ophiolite belt within the NSB at 1900 Ma suggest that D1 cannot be older than this date. This is supported by a recent CHIME age from xenotime from within the Udaygiri Group of $1929 \pm 130 \mathrm{Ma}$ (Das et al. 2015), constraining the upper (older) limit of deformation/ metamorphism in the NSB. D2 deformation in the NFB - and possibly also in the NSB - occurred by $1590 \mathrm{Ma}$ (Saha 2002; Dobmeier et al. 2006; Saha et al. 2010), as indicated by the ages of Vinukonda granite occurring at the western margin of the NSB and those of the syn- to late-tectonic Vellaturu granite that intrudes the NFB. The D3 deformation appears to be much younger, possibly related to PanAfrican tectonothermal rejuvenation in the EGB and adjoining belts, including thrusting of the NFB over the Kurnool Group rocks farther west (Dobmeier and Raith 2003; Saha and Chakraborty 2003; Chakraborti and Saha 2008).

\section{Kanigiri Granite, Contact Relations, and Internal Structures}

The Kanigiri pluton, which has a northeast-southwest-elongated subelliptical outline, crops out north of the town of Kanigiri, covering an area of about $16 \mathrm{~km}^{2}$ (fig. 2). It is a leucocratic, coarse-grained granite, showing an intrusive relationship with slates, phyllites, and quartzites of the Udaygiri Group (fig. 3A). Apart from common mafic microgranular enclaves (MMEs), large $(15 \mathrm{~m} \times 4 \mathrm{~m})$ enclaves of phyllite with refolded folds are present within the Kanigiri granite, particularly in the central part, indicating emplacement of the granite after at least two phases of folding and tectonic foliation development in the Udaygiri Group (fig. 3B, 3C). Such enclaves contain pegmatite veins cutting across phyllitic foliation and interfoliar bands, with very coarse feldspar indicating the contact metamorphic/metasomatic effect of the intrusive Kanigiri granite. Late brittle-ductile shear bands cut across the veins and metasomatized bands in the enclaves and postdate granite emplacement. An intrusive relation with the KOM metachert and metabasalt is also observed along the northwestern boundary of the Kanigiri granite.

Mesoscopic Structures. Granite phases within the Kanigiri pluton are generally massive in appearance, with local relict magmatic foliation. MMEs are common in Kanigiri granite. In the western part of the main body, two distinct types of MMEs are observed: (a) biotite-rich, well-foliated, angular to subrounded, centimeter- to meter-sized MMEs (fig. 4A) and $(b)$ more rounded, isolated, centimeter- to decimeter-sized mesocratic enclaves, sometimes with lobate and frayed 

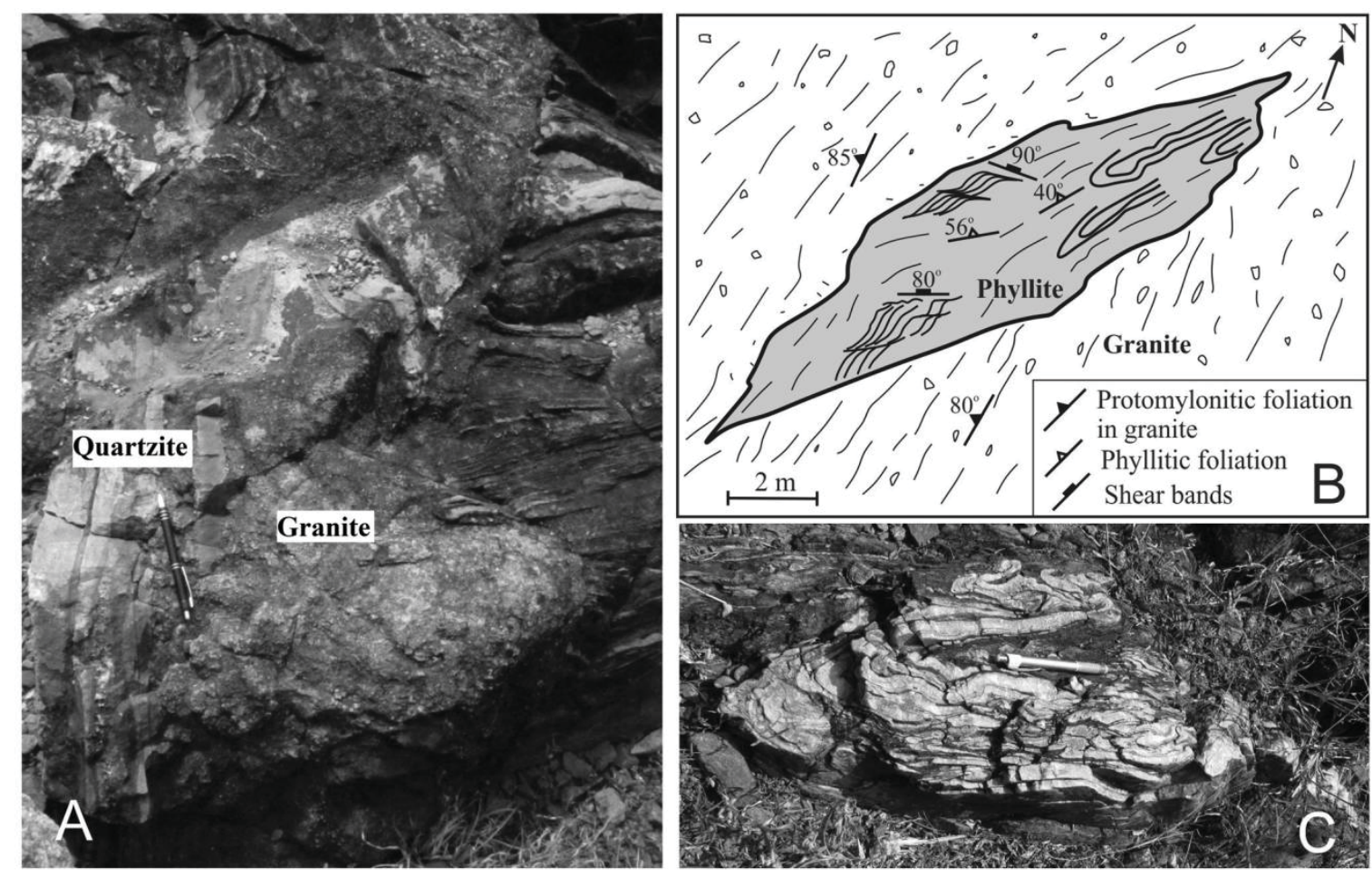

Figure 3. Field photographs showing the intrusive nature of the Kanigiri granite. $A$, Granitic apophyses in quartzites of the Udaygiri Group. B, Large phyllitic enclave in the central part of the Kanigiri granite (field sketch). C, Steeply plunging tight folds in quartz-rich layers in the enclave. A color version of this figure is available online.

margins, diffuse reaction rims, and less pronounced internal fabric (fig. 4B).

A relict magmatic foliation in the Kanigiri pluton is defined by alignment of subhedral feldspar grains and biotite clots that commonly follow the long axis of microgranular enclaves (fig. 4C) and has a predominant northeast-southwest strike with local variations in attitude (fig. 5). Flow bands, defined by variation in grain size, color, and relative abundance of biotite, are also common within the granite body. Sometimes these bands wrap around MMEs (fig. 4A), indicating magmatic to submagmatic flow.

A protomylonitic to mylonitic foliation $(S-L$ to $S>L$ type) is more common in the peripheral part of the Kanigiri granite and in some isolated shear zones and is marked by strong biotite alignment, stretched quartz, and feldspar grains (fig. $4 D$ ) as well as dynamic recrystallization in quartz. In the northeastern peripheral part of the pluton, a mylonitic foliation, defined by the alignment of partly to completely recrystallized biotite grains, ribbons of recrystallized quartz, and feldspar grains, dips steeply toward the southeast, and stretching lineation shows variable plunge toward the south-southeast (fig. 5). In the southwestern part of the main pluton, the mylonitic foliation dips steeply toward the northwest. Local north-south-trending shear zones show a westerly dipping mylonitic foliation with S-C fabric (fig. $4 E$ ). In the central part of the Kanigiri pluton, the subelliptical MMEs show strong alignment of long axes within the weakly foliated host granite (fig. $4 F$ ). Late-stage microgranitic veins are common across the pluton and show sharp contacts with the host granite.

Late shear bands are associated with reduction in grain size, anastomosing foliation with stretched quartz and aligned muscovite and biotite, offset of microgranitic veins and enclaves, and local development of slickensides. The mutual cross-cutting relation of different sets of shear bands indicates that they are broadly contemporaneous.

\section{Petrography and Microstructures}

The dominant petrographic type within the Kanigiri pluton is a coarse-grained, massive to porphyritic gran- 

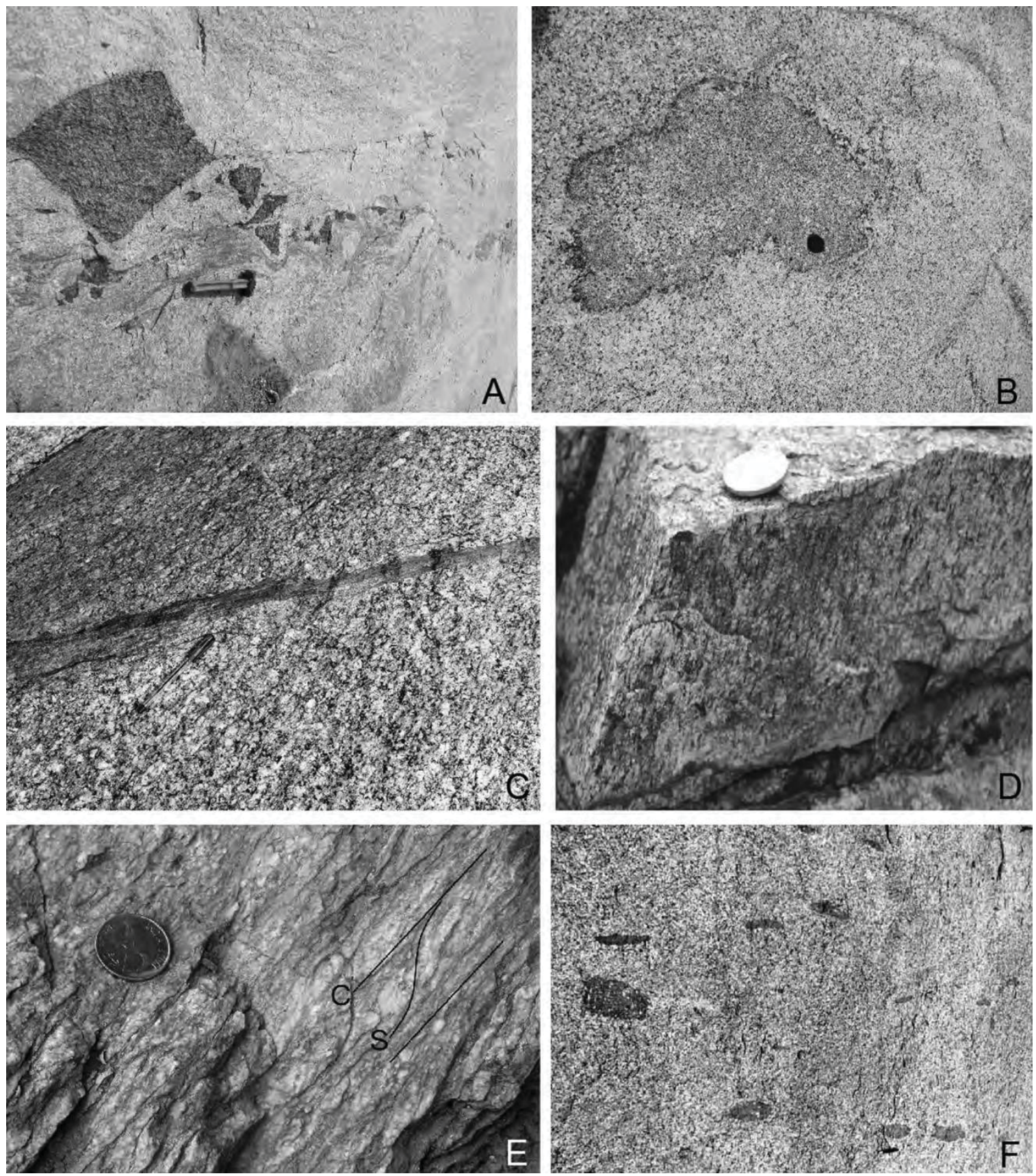

Figure 4. Mafic microgranular enclaves (MMEs) and mesoscopic fabric, Kanigiri granite. $A$, Boudinage train with angular MMEs. Note the flow bands subparallel with the boudinage train and swerving around boudin corners. $B$, Subrounded MME with frayed margin. $C$, Magmatic foliation defined by alignment of subhedral feldspar crystals. $D$, Granite mylonite with stretching lineation (L-S). E, S-C fabric in granite mylonite. F, Flattened and aligned MMEs in outcrop. A color version of this figure is available online. 


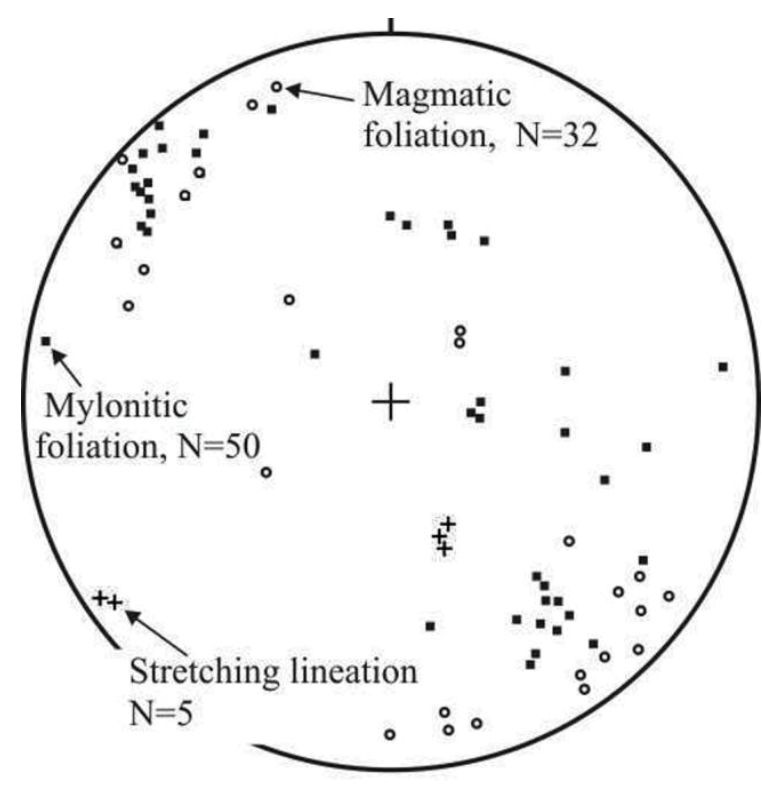

Figure 5. Structural orientations in Kanigirigranite, lower hemisphere equal area projection. Shown are poles to magmatic foliation (open circles), mylonitic foliation (solid squares), and stretching lineation (plus signs).

ite with quartz, alkali feldspar (perthite, microcline microperthite), plagioclase, biotite, and muscovite. Accessory minerals include sphene, epidote, apatite, fluorite, zircon, rutile, and ilmenite. Secondary muscovite and epidote occur as alteration products of feldspar. Biotite is locally altered to chlorite. On the basis of modal composition, the Kanigiri granite is classified as two-mica granite. The mineral composition of the microgranular enclaves is similar to that of the host granite, except for a higher abundance of biotite.

The mineral chemistry of the samples from the Kanigiri granite was determined at the Electron Probe Microanalyser Laboratory, Geological Survey of India, Kolkata. Plagioclase grains are of albitic composition $\left(\mathrm{Ab}_{97-99}\right)$. Biotites are generally Fe rich, and the composition approaches that of pure annite, with $\mathrm{Fe} /(\mathrm{Fe}+\mathrm{Mg})$ ratio varying from 0.97 to 0.99 in the host granite, whereas in the microgranular enclaves the ratio varies from 0.70 to 0.81 .

Microstructure. The Kanigiri granite has two distinctive appearances in outcrops controlled respectively by weaker solid-state deformation, allowing preservation of relict magmatic foliation and strong mylonitization in shear zones. In the weakly deformed domains, the granite is coarse to very coarse grained, with common porphyroclasts of quartz and feldspar and trails of coarse biotite and muscovite wrapping around the porphyroclasts. Quartz porphyroclasts show common undulose extinction, subgrain structure, and peripheral recrystallization, with small recrystallized grains making up to $30 \%$ of the volume proportion of quartz. Some quartz porphyroclasts show a chessboard subgrain pattern, while others show prismatic subgrain boundaries (fig. 6A, 6B). Subgrain rotation recrystallization and bulging recrystallization is also common. Brittle microfractures (microboudinage) are common in perthite and microcline-microperthite grains, with open fractures filled up by recrystallized quartz and mica grains (fig. 6C). Subhedral plagioclase grains show parallelsided growth twins as well as tapering deformation twins or bent and kinked twin lamellae (fig. 6D). Muscovite and biotite grains are commonly kinked. Feldspar porphyroclasts are boudinaged, with some showing $\sigma$-structures and partial recrystallization. In strongly mylonitized domains, oblique grain-shape fabric is defined by alignment of recrystallized and slightly elongated quartz grains $\left(\mathrm{S}_{\mathrm{ob}}\right)$ and concentration of small mica flakes along the mylonitic foliation $\left(S_{\mathrm{m}}\right.$ f fig. $\left.6 E\right)$. Within the shear zones with strong mylonitic foliation, dynamic recrystallization leads to grain-size reduction, with small recrystallized quartz grains (size up to $200 \mu \mathrm{m}$ ) arranged in ribbons and small mica grains making up $\geq 50 \%$ of the aggregate volume (fig. 6F).

An estimate of the magmatic crystallization temperature of the Kanigiri granite is obtained by considering the concentration of $\mathrm{Zr}$ in the bulk-rock samples determined using zircon saturation geothermometry (Watson and Harrison 1983). The crystallization temperatures for the analyzed Kanigiri samples are in the range $750^{\circ}-900^{\circ} \mathrm{C}$ for the peraluminous granite (see also Dharma Rao and Reddy 2007; fig. A1; figs. A1, A2 are available online). The subsolidus deformation of the Kanigiri granite likely occurred below this temperature maximum. The presence of chessboard subgrain structure in quartz indicates subsolidus deformation beginning at least around $550^{\circ} \mathrm{C}$ (Kruhl 1996) in the Kanigiri granite samples with relict magmatic fabric. Prism parallel subgrain boundaries in quartz indicate activation of basal slip, while deformation twins in plagioclase and partial recrystallization in perthite and microcline attest to solidstate deformation of the granite at temperatures $550^{\circ}-$ $450^{\circ} \mathrm{C}$ (Hirth and Tullis 1992; Stipp et al. 2002). While subgrain rotation recrystallization is common, bulging recrystallization in quartz indicates either that dynamic recrystallization continued through still lower temperatures $\left(\mathrm{ca} .400^{\circ}-350^{\circ} \mathrm{C}\right.$ ) or that a later phase of 

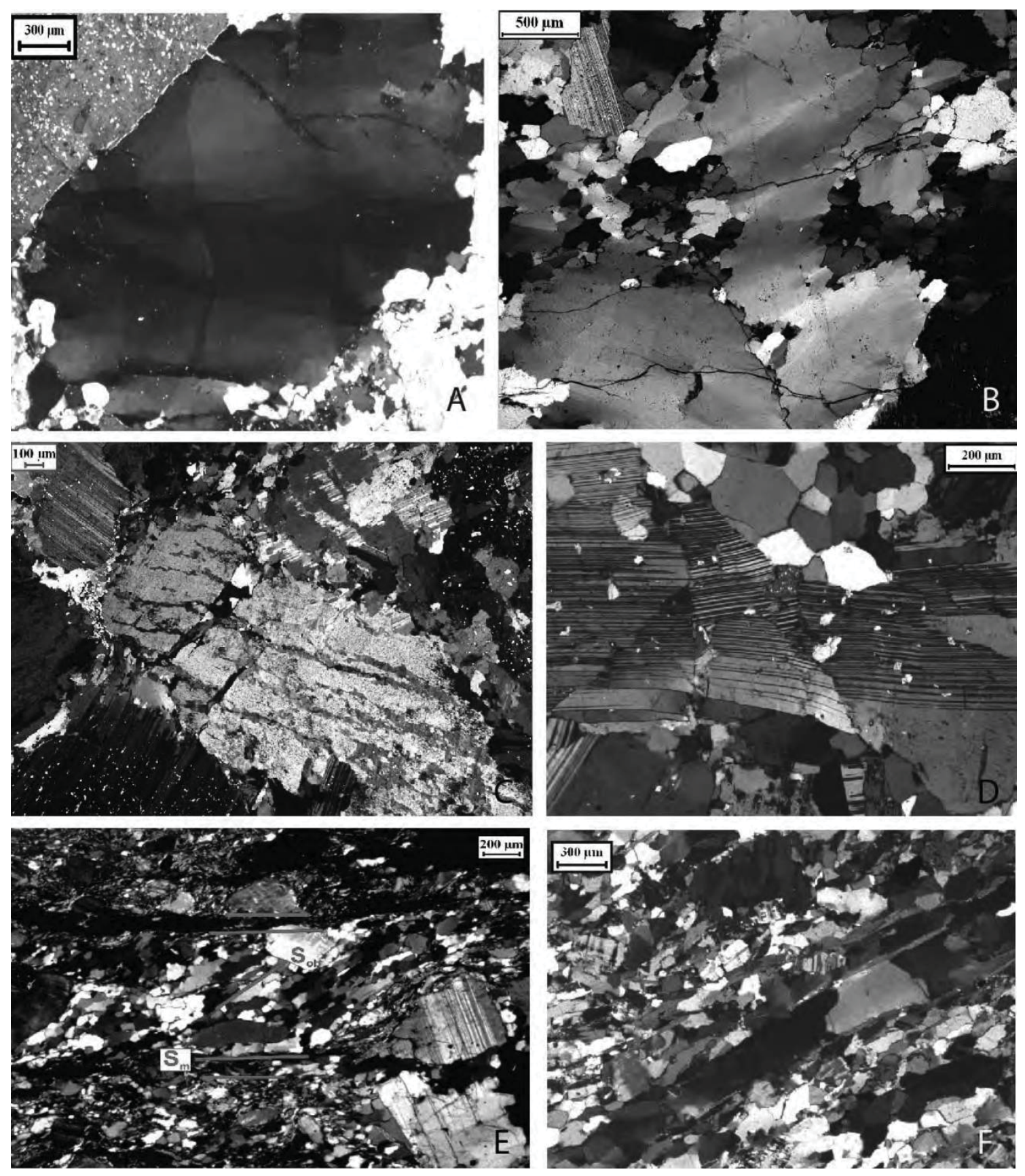

Figure 6. Deformation microstructures, Kanigiri granite. $A$, Chessboard subgrain pattern in quartz, massive to weakly foliated granite. $B$, Marginal recrystallization (arrow) in quartz with undulose core or prismatic subgrain boundary. $C$, Microfracture in perthite with fracture infill of small quartz grains. $D$, Deformation twins and kinks in plagioclase. $E$, Oblique quartz grain shape fabric $\left(\mathrm{S}_{\mathrm{ob}}\right)$ in granite mylonite; note the concentration of biotite flakes along mylonitic foliation $\left(\mathrm{S}_{\mathrm{m}}\right)$. F, Recrystallized quartz and feldspar in granite mylonite, defining ribbons parallel to aligned biotite flakes. A color version of this figure is available online. 


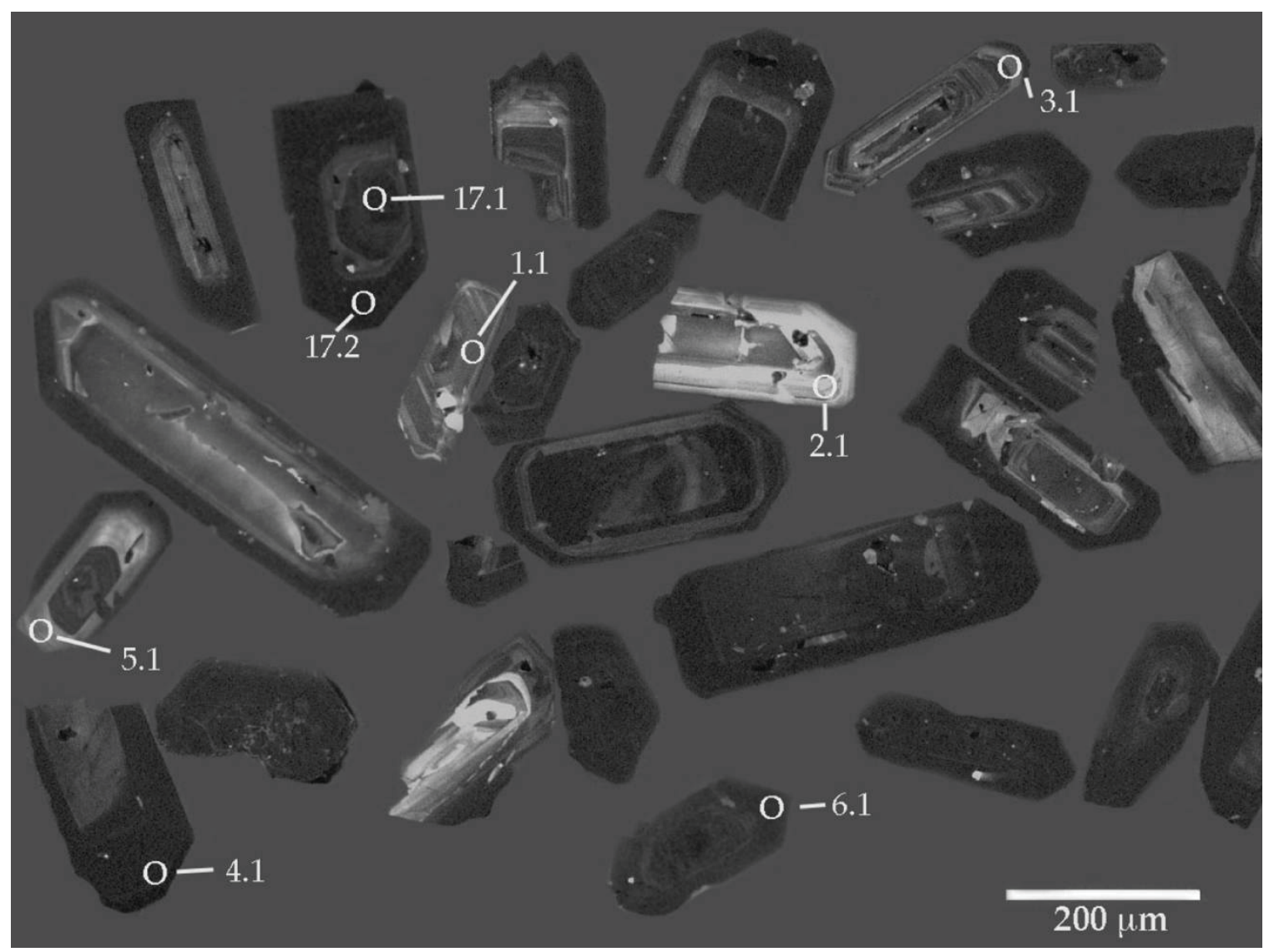

Figure 7. Cathodoluminescence images of representative zircon grains, Kanigiri granite sample EBZ965. The SHRIMP spot sites are marked by white ellipses.

ductile deformation and lower-temperature grain refinement affected the granite.

\section{Geochronology}

The Kanigiri granite was earlier dated by the wholerock $\mathrm{Rb}$-Sr method, which yielded an age of $1125 \pm$ $24 \mathrm{Ma}$ (Gupta et al. 1984). As is often the case with rocks that have undergone multiple deformation and metamorphism, the Rb-Sr method can be unreliable in preserving an original igneous age. Dating by the more robust zircon $\mathrm{U}-\mathrm{Pb}$ method on a freshly collected sample of the A-type Kanigiri granite was carried out to better constrain the emplacement age.

Sample. Rock sample EBZ965 was collected from a locality about $2 \mathrm{~km}$ north of the town of Kanigiri $\left(15.43099^{\circ} \mathrm{N}, 79.50047^{\circ} \mathrm{E}\right)$, from a lower hill slope pavement. The weakly foliated granite is medium grained and composed of white to pale pink feldspar, quartz, and biotite, with fluorite in pegmatite portion and rounded MMEs in the nearby exposure.

Analytical Method. Zircon separation and $\mathrm{U}-\mathrm{Pb}$ ion microprobe isotopic analysis using a SHRIMP II instrument was conducted at the Research School of Earth Sciences, Australian National University, Canberra. Zircon separation was done by standard processing techniques, including rock crushing, heavymineral separation using heavy liquid, magnetic separation using an isodynamic separator, and handpicking under a binocular microscope. Care was taken to ensure that the grains selected for analysis were representative of the zircon population. Analytical procedures followed those outlined by Williams (1998), with data reduction and presentation performed using SQUID version 1.10 and ISOPLOT version 3.0 (Excel macros; Ludwig 2001, 2003). Samples were mounted in epoxy with the zircon standard Temora III before being polished and characterized by various types 


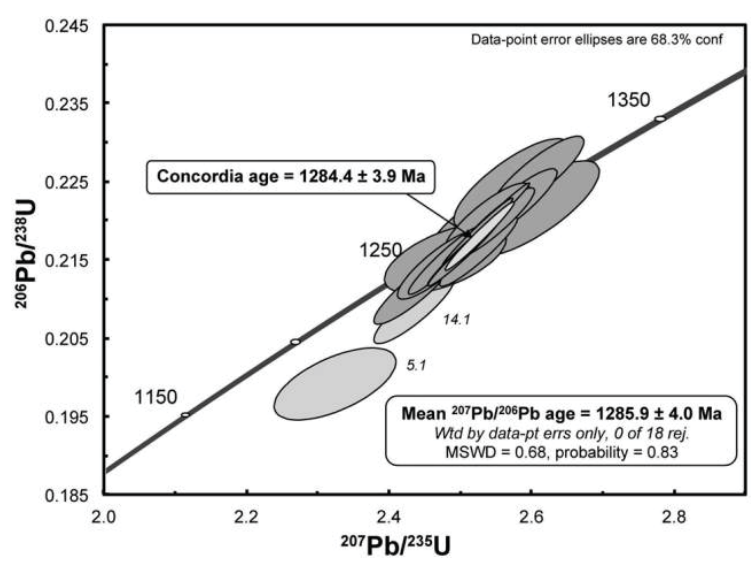

Figure 8. Concordia age diagram of single-grain zircon $\mathrm{U}-\mathrm{Pb}$ SHRIMP analyses on the Kanigiri granite. Uncertainties in the calculated concordia and weighted mean ages are reported as $95 \%$ confidence limits. A color version of this figure is available online.

of imaging (visual, electron). Uncertainties given for individual $\mathrm{U}-\mathrm{Pb}$ analyses (ratios and ages) are at the $1 \sigma$ level; however, uncertainties in the calculated weighted mean ages are reported as $95 \%$ confidence limits and include the uncertainties in the standard calibrations where appropriate (e.g., for the calculation of the concordia age). Corrections for common $\mathrm{Pb}$ were made using the measured ${ }^{204} \mathrm{~Pb}$ and the relevant common $\mathrm{Pb}$ compositions from the Stacey and Kramers (1975) model.

Description of the Zircons. The zircon crystals range in color from light brown to an opaque dark brown, are generally euhedral and elongate (up to $480 \mu \mathrm{m}$ in length), and have well-developed pyramidal terminations. Cathodoluminescence (CL) imaging shows weak concentric zoning and somewhat uncomplicated internal structures, often obscured by dark areas and rims with relatively high $\mathrm{U}$ concentrations. Rare low U areas (bright CL) were mainly targeted for in situ dating, but some high-U tips and other zones were also analyzed to ensure that all zircon types were included (fig. 7).

Results. Despite the high $U$ contents in some grains (up to 3827 ppm; spot 6.1), 16 of the 18 analyzed spots (table S1; tables S1, S2 are available online) cluster on concordia, to give a concordia age of $1284 \pm 4 \mathrm{Ma}$ with a MSWD of 1.1 or a weighted mean ${ }^{207} \mathrm{~Pb} /{ }^{206} \mathrm{~Pb}$ date of $1286 \pm 4 \mathrm{Ma}$ (fig. 8) for all 18 analyses. This result shows that this is a single coeval population of zircons, with no obvious $\mathrm{Pb}$ loss related to the high $\mathrm{U}$ content of some zircons, and no inheritance was detected.

\section{Geochemistry}

The Kanigiri granite was previously classified as an A-type granite (Dharma Rao and Reddy 2007; Sesha Sai 2013). We present here results of new geochemical analyses of the Kanigiri samples and discuss the results in the context of the previous geochemical studies and regional tectonic framework. Eleven fresh quarry samples, representing massive and foliated varieties of the Kanigiri granite, were analyzed (for sample locations, see fig. 2). Both major and trace element abundances were estimated from powdered rock chips at Activation Laboratories (Ontario, Canada). Fused samples were diluted and analyzed by PerkinElmer Sciex ELAN 6000, 6100, or 9000 inductively coupled plasma mass spectrometry (package 4Litho; details at http://www.actlabs .com). FeO was estimated separately by conventional titration (package 4F-FeO). Detection limits are on the order of $0.01 \%$ for major oxides, except for $\mathrm{Mn}$ and $\mathrm{Ti}$, where they are on the order of $0.001 \%$. For rare earth elements (REEs), the detection limit is 0.04-0.1 ppm; for other trace elements, it varies between 0.5 and $5 \mathrm{ppm}$, except for $\mathrm{Cr}(20 \mathrm{ppm}), \mathrm{Ni}$ (20 ppm), and Zn (30 ppm). Sample EBZ965 was analyzed separately at the Council of Geosciences Laboratory, South Africa, using X-ray fluorescence spectrometry. The analytical results are shown in table S2.

Major Oxides. With $\mathrm{SiO}_{2}$ content varying between 68 and $76 \mathrm{wt} \%$, the Kanigiri granite samples fall in the transalkaline to calc-alkaline fields on the TAS diagram (fig. 9A). Alkali contents $\left(\mathrm{Na}_{2} \mathrm{O}+\right.$ $\mathrm{K}_{2} \mathrm{O}$ ) vary from 6.5 to $10.5 \mathrm{wt} \%$ (fig. $9 A$ ) with relatively high $\mathrm{K}_{2} \mathrm{O}(4.1-5.8 \mathrm{wt} \%)$, comparable to high-K to shoshonitic suites (Peccerillo and Taylor 1976). In the classification scheme of Frost et al. (2001), using the $\mathrm{FeO} /(\mathrm{FeO}+\mathrm{MgO})$ versus $\mathrm{SiO}_{2}$ diagram the Kanigiri granite samples plot in the ferroan field (fig. $9 B$ ), whereas using the $\mathrm{A} / \mathrm{NK}$ versus $\mathrm{A} / \mathrm{CNK}$ diagram (Maniar and Piccoli 1989) the samples range from borderline metaluminous to peraluminous (fig. 9C). It is important to note that the Kanigiri granite samples have a low $\mathrm{H}_{2} \mathrm{O}$ content (relatively anhydrous), as apparent from the low loss on ignition (LOI) values $(0.5-1.2 \mathrm{wt} \%)$.

Trace Element Geochemistry. Analyzed samples from the Kanigiri pluton contain relatively low concentrations of low field strength elements (LFSEs) except for $\mathrm{Rb}$ (56-616 ppm), whereas the high field strength element (HFSE) concentrations are relatively high (table S2). However, samples from the eastern part (e.g., KN29) have relatively higher concentrations of LFSEs and lower concentrations of HFSEs than other analyzed samples. 

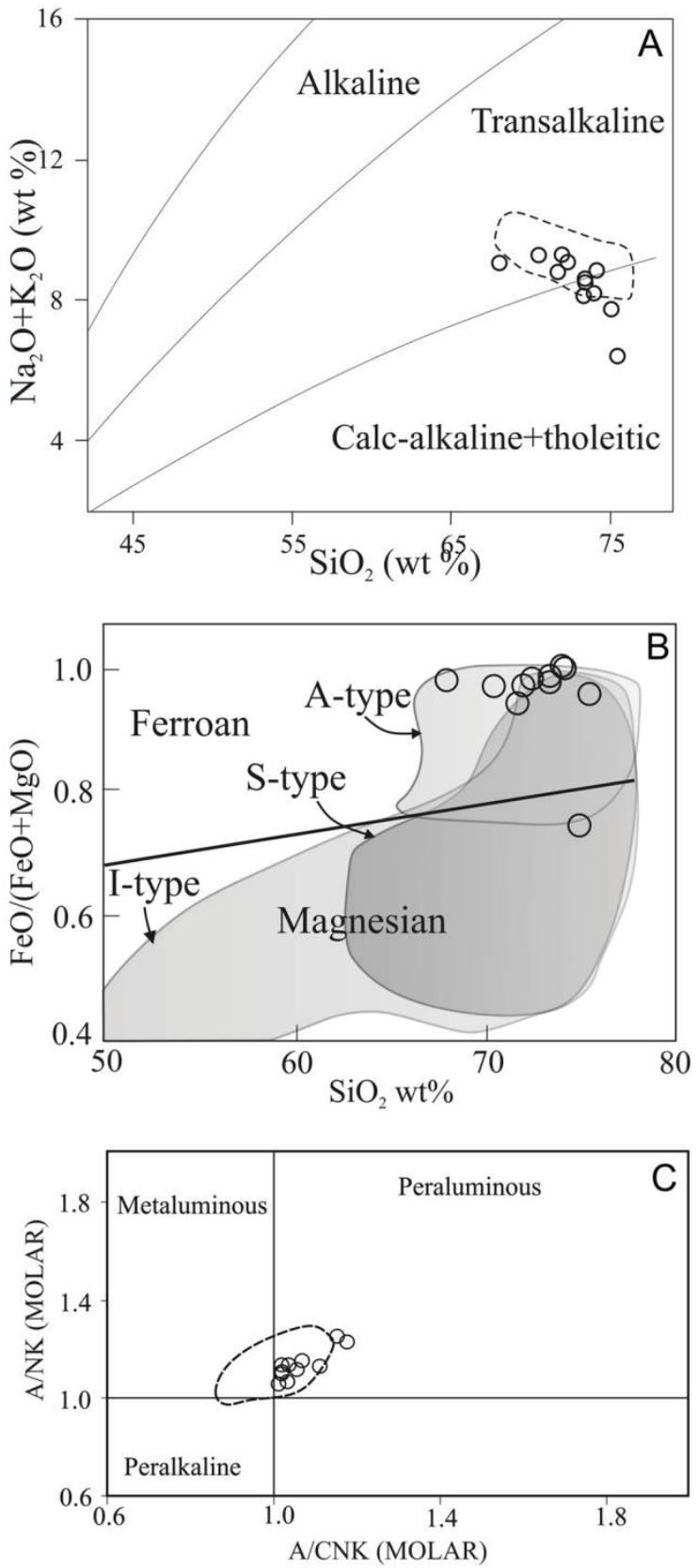

Figure 9. Geochemical variation diagrams. $A$, Total alkali versus silica diagram. $B, \mathrm{Fe}^{*}\left(=\mathrm{FeO}_{\mathrm{t}} /\left(\mathrm{FeO}_{\mathrm{t}}+\mathrm{MgO}\right)\right)$ versus $\mathrm{SiO}_{2}(\mathrm{wt} \%)$. Analyses from Dharma Rao and Reddy (2007) plot inside the area indicated by the dashed outline in $A$ and $C$. $C$, Classification based on molar ratios of $\mathrm{A} / \mathrm{CNK}=\mathrm{Al}_{2} \mathrm{O} 3 /\left(\mathrm{CaO}+\mathrm{Na}_{2} \mathrm{O}+\mathrm{K}_{2} \mathrm{O}\right)$ and $\mathrm{A} / \mathrm{NK}=\mathrm{Al}_{2} \mathrm{O} 3 /$ $\left(\mathrm{Na}_{2} \mathrm{O}+\mathrm{K}_{2} \mathrm{O}\right)$, after Maniar and Piccoli (1989). A color version of this figure is available online.
The normalized ratios of $\mathrm{La}_{\mathrm{N}} / \mathrm{Yb}_{\mathrm{N}}$ vary from 1.4 to 19 , and the $\mathrm{Ce}_{\mathrm{N}} / \mathrm{Yb}_{\mathrm{N}}$ ratio varies from 1.2 to 15.7 , indicating a high degree of fractionation. The normalized ratio for the lighter elements - that is, $\mathrm{La}_{\mathrm{N}} /$ $\mathrm{Sm}_{\mathrm{N}}$-varies from 1.5 to 6.4 , whereas the ratio of $\mathrm{Tb}_{\mathrm{N}} / \mathrm{Yb}_{\mathrm{N}}$ for heavier elements ranges from 0.14 to 1.5 , indicating relatively lesser degrees of fractionation of heavy REEs compared with light REEs (LREEs; fig. 10A). The primitive mantle-normalized multielement spider diagram shows $\mathrm{Cs}$ and $\mathrm{Rb}$ enrichment. The strong negative Eu anomaly, as well as negative $\mathrm{Ba}, \mathrm{Sr}, \mathrm{P}$, and $\mathrm{Ti}$ anomalies, may be related to feldspar, apatite, and ilmenite/magnetite fractionation (Eby 1992) in the granite (fig. 10B). The Kanigiri samples are also enriched in HFSEs, and on a $10,000 \mathrm{Ga} / \mathrm{Al}$ versus $\mathrm{Zr}$ (or $\mathrm{Nb}$ ) plot (not shown) the samples fall in the A-type granite field (Whalen et al. 1987). Considering the relative abundance of $\mathrm{Nb}, \mathrm{Y}$, and $\mathrm{Ce}$ (or Nb-Y-3* Ga) as proposed by Eby (1992) for geochemical discrimination, most of the Kanigiri samples can be classified as belonging to the A1 subtype (fig. A2).

\section{Discussion and Conclusions}

Gradation from Primary Magmatic Fabric to Tectonic Fabric. Primary magmatic fabrics are developed within granite bodies in response to magmatic flow due to buoyancy forces or thermal or compositionally driven convections. The shape of the intrusions and the regional strain conditions are also responsible for the formation of the magmatic fabrics. Magmatic foliations are defined by the alignment of igneous, commonly euhedral to subhedral minerals with platy, tabular, or acicular shapes and developed during a late stage of crystallization of a magma batch with a melt proportion of $<25 \%$ (Paterson et al. 1998). The estimated temperature of magmatic crystallization of the Kanigiri granite from $\mathrm{Zr}$ saturation geothermometry (Watson and Harrison 1983) is on the order of $750^{\circ}-900^{\circ} \mathrm{C}$ (fig. A1). The tectonic fabrics are developed due to the solid-state deformation of the granite during further cooling, by enhancing the original fabric and/or overprinting by a newly acquired secondary fabric (Vernon 2000).

In the Kanigiri granite body, magmatic foliations show a subparallel alignment with the tectonic foliation in the marginal part. At the western part, both types of foliation dip steeply northwest, whereas at the northeastern side foliations dip steeply southeast. In the central part of the pluton, magmatic foliations are sparsely developed and show little preferred orientation, whereas at the margin of the granite body the relict magmatic foliation follows the overall 

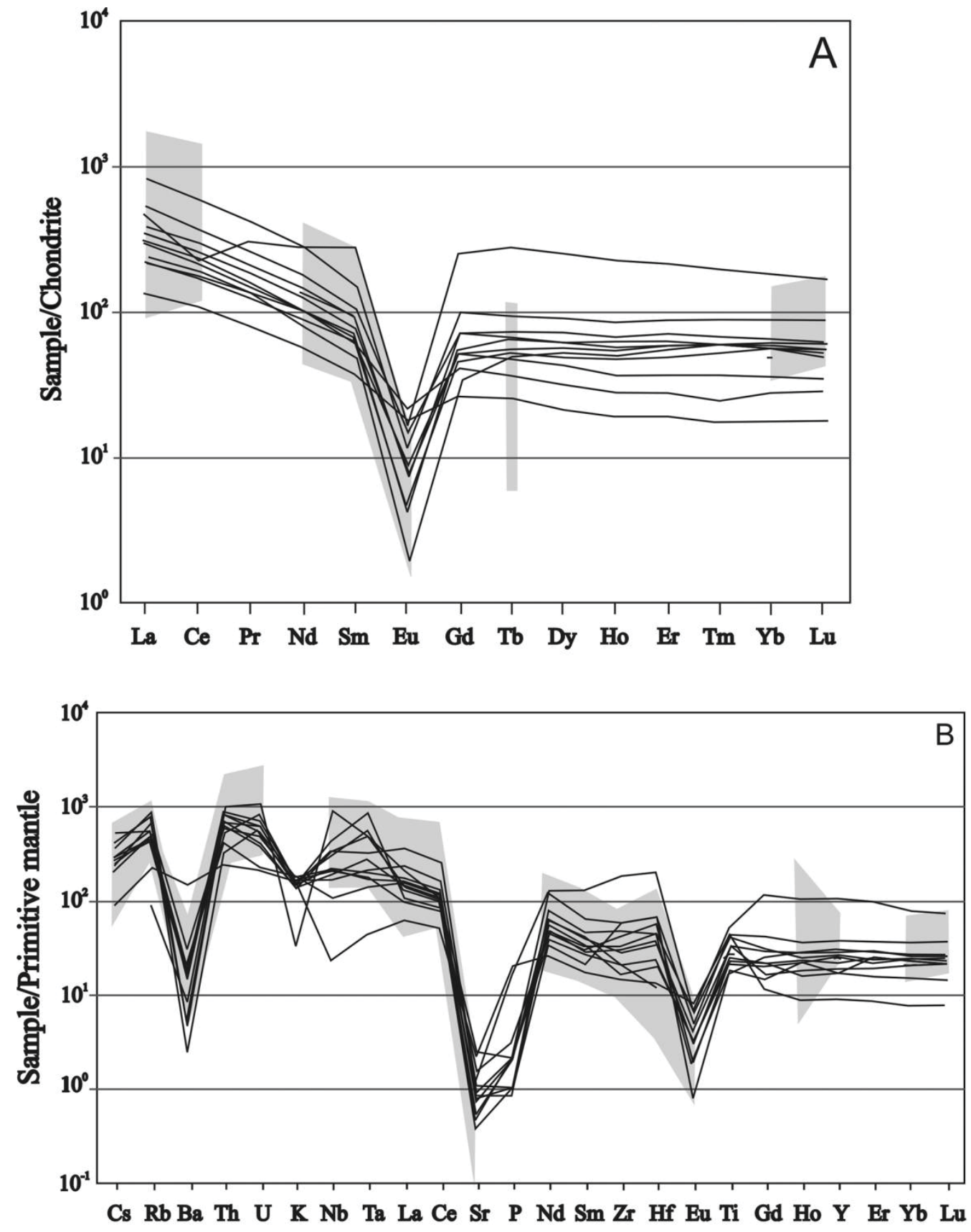

Figure 10. Normalized trace element abundances, Kanigiri granite. $A$, Chrondrite normalized rare earth element abundances; normalization factors after Boynton (1984). B, Primitive mantle-normalized spider diagrams; normalization factors after Sun and McDonough (1989). Data fields from Dharma Rao and Reddy (2007) are shown shaded in both of the plots. A color version of this figure is available online.

northeast-southwest trend of the granite body. While the increased flattening may be due to pulsed emplacement of magma batches (cf. ballooning plutons or nested diapirs; e.g., Paterson et al. 1989; Ramsay
1989; Paterson and Vernon 1995; Schoene et al. 2012), one cannot rule out the influence of late tectonic regional stress during the late stage of accretion of the KOM or imprints of younger orogenic event/s) along 
the margin of the Dharwar craton, as evidenced by major tectonothermal events recorded from the Eastern Ghats belt (Shaw et al. 1997; Sarkar and Paul 1998; Mezger and Cosca 1999; Rickers et al. 2001; Dobmeier and Raith 2003; Simmat and Raith 2008). Of particular relevance here is the ca. $980-930 \mathrm{Ma}$ ultrahigh temperature metamorphism and orogenesis in the central part of the Eastern Ghats province (Korhonen et al. 2011).

Subsolidus Deformation of the Kanigiri Granite: Transition from Magmatic Temperature to Upper Crustal Temperature. Microstructures and fabrics evolve as the granite plutons pass through stages of initial magma pooling, subsequent increase in volume, intrusion, cooling, and finally exhumation to their present erosion level. While the magmatic fabric may remain as palimpsest, subsolidus deformation overprinting, whether triggered by contemporaneous regional strain or the result of emplacementrelated strain, influences the bulk of the observed microstructures as the pluton cools through the ductile to brittle regime in the middle to upper crust. Three distinct quartz recrystallization processes, active at different temperature regimes, have been recognized (cf. Hirth and Tullis 1992; Stipp et al. 2002; Passchier and Trouw 2006; Saha and Chakraborty 2007; Zibra et al. 2012).

As described earlier, the Kanigiri granite is mylonitized to varying degrees in the shear zones at the margin or traversing the interior of the granite body (fig. 2). Thin sections of granite mylonite samples show partly to fully recrystallized quartz ribbons wrapping around partly recrystallized feldspar porphyroclasts. The quartz microstructures indicate crystal plastic deformation during cooling of the granite. The chessboard pattern subgrain boundaries in quartz (Kruhl 1996) represent moderate- to high-temperature $\left(>550^{\circ} \mathrm{C}\right)$ deformation preserved in the massive to weakly foliated granite locally retaining magmatic foliation. However, the hightemperature grain boundary migration recrystallization in quartz is far more common in the shear zones with strong mylonitic foliation. Bulging recrystallization and prism-parallel subgrain boundaries indicate low-temperature deformation overprinting.

The moderate- to high-temperature deformation microstructures $\left(500^{\circ}-650^{\circ} \mathrm{C}\right)$ represent amphibolite facies conditions, whereas the low-temperature deformation microstructures $\left(300^{\circ}-600^{\circ} \mathrm{C}\right)$ represent low to middle greenschist facies conditions. Thus, a part of the deformation and microstructural development occurred under retrograde conditions, suggesting late- to posttectonic emplacement and/or deformation during a later tectonic cycle.
Tectonic Setting and Origin of the Kanigiri Granite. The bulk geochemistry of the Kanigiri samples indicates that these share the essential features of A-type granite in being alkali-calcic to calc-alkaline and having high $\mathrm{Fe} / \mathrm{Mg}$ ratios, high $\mathrm{K}_{2} \mathrm{O} / \mathrm{Na}_{2} \mathrm{O}$ ratios, and low $\mathrm{H}_{2} \mathrm{O}$ (as inferred from low LOI; Loiselle and Wones 1979; Creaser et al. 1991; Eby 1992; Frost et al. 2001; Dharma Rao and Reddy 2007; Sesha Sai 2013). The major element geochemistry of the Kanigiri granite is quite distinct from that of the felsic alkaline plutons of the PAkP, for example, the Elchuru syenite, which has total alkali content varying between $6 \%$ and $15 \%$ and $\mathrm{SiO}_{2}$ ranging between $53 \%$ and $60 \%$ (Nag et al. 1984). The Kanigiri samples are relatively enriched in lithophile elements like $\mathrm{Rb}$ and $\mathrm{Cs}$, REEs, and HFSEs like $\mathrm{Zr}$ and $\mathrm{Nb}$. However, the presence of both primary biotite and muscovite, as well as ilmenite as the main opaque mineral in the granite, indicate that it also has some characters of S-type granite (Clarke 1981). The biotites are mainly annite, suggesting close similarity with the mineral chemistry of A-type granite (AbdelRahman 1994). Sesha Sai (2013) also suggested a sedimentary source for the Kanigiri granite on the basis of mineral composition and the low $\mathrm{Na}_{2} \mathrm{O} / \mathrm{K}_{2} \mathrm{O}$ ratios. The interpretation regarding tectonic settingbased geochemical discrimination tools is not unambiguous in the case of the Kanigiri granite (see also Sesha Sai 2013). In the $\mathrm{R}_{1}-\mathrm{R}_{2}$ plot (De La Roche et al. 1980), the samples fall close to the borderline between syncollisional and postorogenic or anorogenic settings (fig. 11A). On the other hand, on a ternary plot based on $\mathrm{Rb} / 30-\mathrm{Hf}-3^{*} \mathrm{Ta}$ abundance (Harris et al. 1986) the granite appears to have been emplaced in a late- and postcollisional to within-plate setting (fig. 11B).

The trace element abundances and the negative anomalies of $\mathrm{Ba}, \mathrm{Sr}, \mathrm{P}, \mathrm{Ti}$, and $\mathrm{Yb}$ in the primitive mantle-normalized spider diagram (fig. 10B) are similar to those of the cordilleran-type Cretaceous Ankoret granite from Southeast Asia, which was emplaced in a postcollisional setting within a collisional belt (Shellnutt et al. 2013). The Kanigiri granite intruded the KOM, the latter representing an accretionary orogen. Dharma Rao et al. (2011) suggested that the late phases of tectonic convergence in the KOM and vicinity possibly continued until $1000 \mathrm{Ma}$. The $1285 \mathrm{Ma}$ zircon U-Pb age of the Kanigiri granite as obtained in the present study is consistent with a late- to postorogenic setting interpreted on the basis of geochemical discrimination (fig. 11B; Harris et al. 1986).

While the mineral composition of the Kanigiri granite (two-mica granite) favors involvement of a metasedimentary source, as in S-type granite (Sesha 

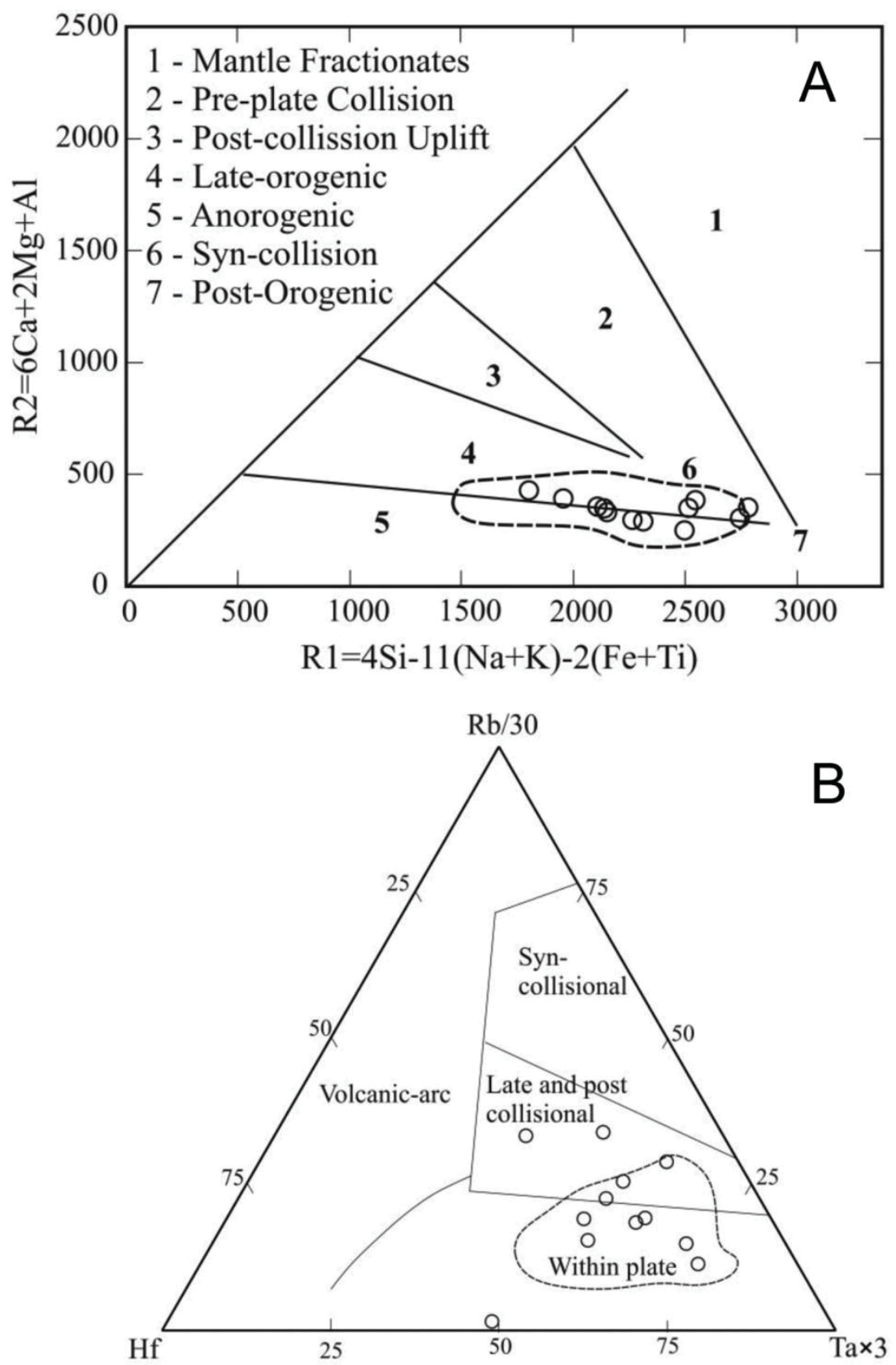

Figure 11. Geochemical discrimination of the tectonic setting of the Kanigiri granite. $A, \mathrm{R}_{1}-\mathrm{R}_{2}$ diagram, after De La Roche et al. (1980). Kanigiri granite samples straddle across anorogenic, late-orogenic, and syncollisional fields. $\mathrm{R}_{1}=$ $4 \mathrm{Si}-11(\mathrm{Na}+\mathrm{K})-2(\mathrm{Fe}+\mathrm{Ti}) ; \mathrm{R}_{2}=(6 \mathrm{Ca}+2 \mathrm{Mg})+\mathrm{Al}$. B, Hf-Rb/30-Ta*3 discrimination diagram after Harris et al. (1986). Data fields from Dharma Rao and Reddy (2007) are shown by the dashed outline.

Sai 2013), high $\mathrm{FeO}^{\mathrm{T}}$, strong LREE fractionation, and negative Eu anomaly are the hallmark of A-type granite. Eby (1992) distinguished two subtypes within A-type granites and, based on results from known
A-type granites from different areas, concluded that the Al subtype has an origin linked to granite associated with ocean island basalt. The Kanigiri samples also have an A1 subtype character (fig. A2), which sug- 
gests that fractional crystallization of basaltic magma probably yielded a felsic derivative and later the intrusive granite. The relatively small size of the Kanigiri granite body was probably controlled by a small volume of the derived felsic magma, as proposed for late- or postorogenic granites (Rogers and Greenberg 1990). The bulk chemistry of the Kanigiri granite with low LOI is indicative of relatively anhydrous source magma.

Implications of the New SHRIMP Age from Kanigiri Granite. The new zircon SHRIMP date from Kanigiri sample EBZ965 yielded a concordant age of $1284 \pm 3.9 \mathrm{Ma}$, indicating the age of intrusion and subsolidus crystallization. As the Kanigiri granite shows an intrusive relationship with the KOM rocks dated at $1334 \mathrm{Ma}$ (Dharma Rao et al. 2011), the tectonic accretion of the KOM onto the eastern Dharwar craton margin was followed by a tectonic hiatus of about 50 m.yr. before intrusion of the Kanigiri granite. The overprinting of high-temperature crystal plastic microstructures in the granite by relatively low-temperature recrystallization features leads us to suggest that following its initial emplacement, the Kanigiri granite underwent deformation and retrograde metamorphism during a younger tectonic episode affecting the multiply deformed NSB. The A-type igneous plutons of Kanigiri and neighboring areas, therefore, appear to have been emplaced during a late- to postorogenic phase (cf. Rogers and Greenberg 1990). The hiatus of 50 m.yr. between cessation of an orogeny and subsequent generation of A-type granites compares well with the known data from various areas across the world (e.g., Frost et al. 2001; Oyhantçabal et al. 2007; Bickford et al. 2015; Roberts et al. 2015). However, the $\mathrm{SiO}_{2}$-rich alkali-calcic to calc-alkalic Kanigiri granite with high $\mathrm{FeO}^{\mathrm{T}}$ is compositionally distinct from the other PAkP plutons, for example, the Elchuru syenite, earlier interpreted as representing rift-related alkaline magmatism. The present work upholds the notion that A-type granites form in varied tectonic settings and are not necessarily restricted to a rift setting.

\section{A C K N O W LE D G M ENTS}

This work is funded by the Indian Statistical Institute. A. Sain acknowledges receipt of a Senior Research Fellowship from the institute during the course of this work. Support from the De Beers Group is acknowledged by S. Joy and H. Jelsma. Constructive reviews of early versions of the manuscript by P. Bickford and G. Grantham are thankfully acknowledged.

\section{REFERENCES CITED}

Abdel-Rahman, A.-F. M. 1994. Nature of biotites from alkaline, calc-alkaline and peraluminous magma. J. Petrol. 35:525-541.

Barbarian, B. 1999. A review of the relations between granitoid types, their origins and their geodynamic environments. Lithos 46:605-626.

Bickford, M.E.; van Schmus, W.R.; Karlstorm, K.E.; Mueller, P. A.; and Kamenov, G. D. 2015. Mesoproterozoic-transLaurentian magmatism: a synthesis of continent-wide age distributions, new SIMS U-Pb ages, zircon saturation temperatures, and $\mathrm{Hf}$ and $\mathrm{Nd}$ isotopic compositions. Precambrian Res. 265:286-312.

Boynton, W. V. 1984. Cosmochemistry of the rare earth elements: meteorite studies. In Henderson, P., ed. Rare earth element geochemistry (vol. 2). Developments in Geochemistry. New York, Elsevier, p. 63-114.

Chakraborti, S., and Saha, D. 2008. Tectonic stresses and thin-skinned tectonics in a Proterozoic fold-and-thrust belt read from calcite mylonites in the Cuddapah Basin, South India. India J. Geol. 78:37-54.

Chappell, B. W., and White, A. J. R. 1974. Two contrasting granite types. Pac. Geol. 8:173-174.

Clarke, D. B. 1981. The mineralogy of peraluminous granites: a review. Can. Mineral. 19:3-17.

Creaser, R. A.; Price, R. C.; and Wormald, R. J. 1991. A-type granites revisited: assessment of a residualsource model. Geology 19:163-166.
Das, S.; Shukla, D.; Bhattacharjee, S.; and Mitra, S. K. 2015. Age constraints of Udaygiri domain of Nellore schist belt by xenotimes dating around Pamuru, Prakasam district, Andhra Pradesh. J. Geol. Soc. India 85:289-298.

De La Roche, H.; Leterrier, J.; Grandclaude, P.; and Marchal, M. 1980. A classification of volcanic and plutonic rocks using $\mathrm{R}_{1}-\mathrm{R}_{2}$-diagram and major-element analyses -its relationships with current nomenclature. Chem. Geol. 29:183-210.

Dharma Rao, C. V., and Reddy, U. V. B. 2007. Petrology and geochemistry of Paleoproterozoic A-type granite at Kanigiri in the Nellore-Khammam schist belt, Andhra Pradesh, India. J. Asian Earth Sci. 30:1-19.

Dharma Rao, C. V.; Santosh, M.; and Yuan-Bao, W. 2011. Mesoproterozoic ophiolitic mélange from the SE periphery of the Indian plate: U-Pb zircon ages and tectonic implications. Gondwana Res. 19:384-401.

Dobmeier, C.; Lutke, S.; Hammerschmidt, K.; and Mezger, K. 2006. Emplacement and deformation of the Vinukonda metagranite (Eastern Ghats, India): implications for the geological evolution of peninsular India and for Rodinia reconstructions. Precambrian Res. 146:165188.

Dobmeier, C., and Raith, M. M. 2003. Crustal architecture and evolution of the Eastern Ghats belt and adjacent regions of India. In Yoshida, M.; Windley, B. F.; and Dasgupta, S., eds. Proterozoic east Gondwana: super- 
continent assembly and breakup. Geol. Soc. Lond. Spec. Pub. 206:145-168.

Eby, G. N. 1990. The A-type granitoids: a review of their occurrence and chemical characteristics and speculations on their petrogenesis. Lithos 26:115-134.

- 1992. Chemical subdivision of the A-type granitoids: petrogenetic and tectonic implications. Geology 20:641-644.

Frost, B. R.; Barnes, C. G.; Collins, W. J.; Arculus, R. J.; Ellis, D. J.; and Frost, C. D. 2001. A geochemical classification for granitic rocks. J. Petrol. 42:2033-2048.

Ghosh, D.; Das, J. N.; Rao, A. K.; Ray Barman, T.; Kollapuri, V. K.; and Sarkar, A. 1994. Fission-track and $\mathrm{K}$-Ar dating of pegmatite and associated rocks of Nellore schist belt, Andhra Pradesh: evidence of Middle to Late Proterozoic events. India Mineral. 48:95-102.

Gupta, J. N.; Pandey, B. K.; Chabria, T.; Banerjee, D. C.; and Jayaram, K. M. V. 1984. Rb-Sr geochronological studies on the granites of Vinukonda and Kanigiri, Prakasam District, Andhra Pradesh, India. Precambrian Res. 26:105-109.

Harris, N. B. W.; Pearce, J. A.; and Tindle, A. G. 1986. Geochemical characteristics of collision zone magmatism. In Coward, M. P., and Reis, A. C., eds. Collision tectonics. Geol. Soc. Lond. Spec. Pub. 19:67-81.

Henderson, B.; Collins, A. S.; Payne, J.; Forbes, C.; and Saha, D. 2014. Geologically constraining India in Columbia: the age, isotopic provenance and geochemistry of the protoliths of the Ongole domain, southern Eastern Ghats, India. Gondwana Res. 26:888-906.

Hirth, G., and Tullis, J. 1992. Dislocation creep regimes in quartz aggregates. J. Struct. Geol. 14:145-159.

Korhonen, F. J.; Saw, A. K.; Clark, C.; Brown, M.; and Bhattacharya, S. 2011. New constraints on UHT metamorphism in the Eastern Ghats province through the application of phase equilibria modelling and in situ geochronology. Gondwana Res. 20:764-781.

Krishna Reddy, K. K.; Ratnakar, J.; and Leelanandam, C. 1998. A petrochemical study of the Proterozoic alkaline complex of Uppalapdu, Prakasam alkaline province, Andhra Pradesh. J. Geol. Soc. India 53:41-52.

Kruhl, J. H. 1996. Prism- and basal-plane parallel subgrain boundaries in quartz: a microstructural geothermobarometer. J. Metam. Geol. 14:581-589.

Leelanandam, C. 1989. The Prakasam alkaline province in Andhra Pradesh, India. J. Geol. Soc. India 34:25-45.

Leelanandam, C.; Burke, K.; Ashwal, L. D.; and Webb, S. J. 2006. Proterozoic mountain building in peninsular India: an analysis based primarily on alkaline rock distribution. Geol. Mag. 143:195-212.

Loiselle, M. C., and Wones, D. R. 1979. Characteristics and origin of anorogenic granites. Geol. Soc. Am. Abstr. Programs 11:468.

Ludwig, K. R. 2001. SQUID 1.03: a user's manual. Special Publication No. 2. Berkley, CA, Berkley Geochronology Center, $2-19 \mathrm{p}$.

2003. Isoplot 3.0: a geochronological toolkit for Microsoft Excel. Special Publication No. 4. Berkley, CA, Berkley Geochronology Center, 70 p.
Maniar, P. D., and Piccoli, P. M. 1989. Tectonic discriminations of granitoids. Geol. Soc. Am. Bull. 101:635643.

Mezger, K., and Cosca, M. 1999. The thermal history of the Eastern Ghats belt (India), as revealed by U-Pb and ${ }^{40} \mathrm{Ar} /{ }^{39} \mathrm{Ar}$ dating of metamorphic and magmatic minerals: implications for the SWEAT correlation. Precambrian Res. 94:251-271.

Moeen, S. 1998. P-T estimates from Nellore schist belt, India and evidence for superimposed metamorphic events. Geol. J. 33:1-15.

Nag, S.; Chakravorty, P. S.; Smith, T. E.; and Huang, C. H. 1984. The petrology and geochemistry of intrusive alkaline rocks of Elchuru, Prakasam district, Andhra Pradesh, India. Geol. J. 19:57-76.

Oyhantçabal, P.; Siegesmund, S.; Wemmer, K.; Frei, R.; and Layer, P. 2007. Post-collisional transition from calcalkaline to alkaline magmatism during transcurrent deformation in the southernmost Dom Feliciano belt (Braziliano-Pan-African, Uruguay). Lithos 98:141-159.

Passchier, C. W., and Trouw, R. A. J. 2006. Microtectonics (2nd ed.). Berlin, Springer, p. 56-59.

Paterson, S. R.; Fowler, T. K., Jr.; Schmidt, K. L.; Yoshinobu, A. S.; Semele Yuan, E.; and Miller, R. B. 1998. Interpreting magmatic fabric pattern in plutons. Lithos 44:53-82.

Paterson, S. R., and Vernon, R. H. 1995. Bursting the bubble of ballooning plutons: a return to nested diapirs emplaced by multiple processes. Geol. Soc. Am. Bull. 107:1356-1380.

Paterson, S. R.; Vernon, R. H.; and Tobisch, O. T. 1989. A review of criteria for the identification of magmatic and tectonic foliations in granitoids. J. Struct. Geol. 11: 349-363.

Peccerillo, R., and Taylor, S. R. 1976. Geochemistry of Eocene calc-alkaline volcanic rocks from the Kastamonu area, northern Turkey. Contrib. Miner. Petrol. 58:63-81

Ramam, P. K., and Murty, V. N. 1997. Geology of Andhra Pradesh. Geol. Soc. India (Bangalore), 56-63 p.

Ramsay, J. G. 1989. Emplacement kinematics of a granite diapir: the Chindamora batholith, Zimbabwe. J. Struct. Geol. 11:191-209.

Ratnakar, J., and Leelanandam, C. 1989. Petrology of the alkaline plutons from the eastern and southern peninsular India. Geol. Soc. India Mem. 15:145-176.

Ratnakar, J., and Vijaya Kumar, K. 1995. Petrogenesis of quartz-bearing syenite occurring within nepheline syenite of the Elchuru alkaline complex, Prakasam province, Andhra Pradesh, India. J. Geol. Soc. India 46:611-618.

Ravikant, V. 2010. Palaeoproterozoic (1.9 Ga) extension and breakup along the eastern margin of the eastern Dharwar craton, SE India: new Sm-Nd isochron age constraints from anorogenic mafic magmatism in the Neoarchean Nellore greenstone belt. J. Asian Earth Sci. 37:67-81.

Rickers, K.; Mezger, K.; and Raith, M. M. 2001. Evolution of the continental crust in the Proterozoic Eastern Ghats belt, India and new constraints for Rodinia re- 
construction: implications from $\mathrm{Sm}-\mathrm{Nd}, \mathrm{Rb}-\mathrm{Sr}$ and $\mathrm{Pb}-\mathrm{Pb}$ isotopes. Precambrian Res. 112:183-210.

Roberts, N. M. W.; Slagstad, T.; and Viola, G. 2015. The structural, metamorphic and magmatic evolution of Mesoproterozoic orogens. Precambrian Res. 265:1-9.

Rogers, J. W., and Greenberg, J. K. 1990. Late-orogenic, post-orogenic, and anorogenic granites: distinction by major-element and trace-element chemistry and possible origins. J. Geol. 98:291-309.

Saha, D. 2002. Multistage deformation in the Nallamalai fold belt, Cuddapah Basin, South India-implications for Mesoproterozoic tectonism along the southeastern margin of India. Gondwana Res. 5:701-709.

. 2004. Structural asymmetry and plate tectonic set-up for a Proterozoic fold-and-thrust belt: Nallamalai fold belt and adjoining terrane, South India. Geol. Sur. India Spec. Pub. 84:101-119.

—. 2011. Dismembered ophiolites in Paleoproterozoic nappe complex of Kandra and Gurramkonda, South India. J. Asian Earth Sci. 42:158-175.

Saha, D., and Chakraborty, S. 2003. Deformation pattern in the Kurnool and Nallamalai Groups in the northeastern part (Palnad area) of the Cuddapah Basin South India and its implication on Rodinia/Gondwana tectonics. Gondwana Res. 6:573-583.

- 2007. Advective heat transfer and fabric development in a shallow crustal intrusive granite - the case of Proterozoic Vellaturu granite, South India. J. Earth Syst. Sci. 116:433-450.

Saha, D.; Chaktaborti, S.; and Tripathy, V. 2010. Intracontinental thrusts and inclined transpression along eastern margin of the east Dharwar craton, India. J. Geol. Soc. India 75:323-337.

Saha, D.; Sain, A.; Kundu, P.; Mazumder, R.; and Kar, R. 2015. Tectonostratigraphic evolution of the Nellore schist belt, southern India, since the Neoarchean. In Mazumder, R., and Eriksson, P. G., eds. Precambrian basins of India: stratigraphic and tectonic context. Geol. Soc. Lond. Mem. 43:269-282.

Saha, D.; Sain, A.; and Nandi, P. 2011. Structures in parts of Nellore schist belt and clues to tectonic evolution of the SE margin of India in the Proterozoic (abstract). In Geodynamics and metallogenesis of the Indian lithosphere. Varanasi, Banaras Hindu University, 26 p.

Santosh, M. 2012. Indian's Palaeoproterozoic legacy. In Mazumder, R., and Saha, D., eds. Paleoproterozoic of India. Geol. Soc. Lond. Spec. Pub. 365:5-29.

Sarkar, A., and Paul, D. K. 1998. Geochronology of the Eastern Ghats Precambrian mobile belt-a review. Geol. Sur. India Spec. Publ. 44:51-86.

Schoene, B.; Schaltegger, U.; Brack, P.; Latkoczy, C.; Stracke, A.; and Gunther, D. 2012. Rates of magma differentiation and emplacement in a ballooning pluton recorded by U-Pb TIMS-TEA, Adamello batholith, Italy. Earth Planet. Sci. Lett. 355-356:162-173.

Sesha Sai, V. V. 2009. Sheeted dykes in Kandra ophiolite complex, Nellore schist belt, Andhra Pradeshvestiges of Precambrian oceanic crust. J. Geol. Soc. India 74:509-514.
2013. Proterozoic granite magmatism along the terrane boundary tectonic zone to the east of Cuddapah Basin, Andhra Pradesh-petrotectonic implications for Precambrian crustal growth in Nellore schist belt of eastern Dharwar craton. J. Geol. Soc. India 81:167-182.

Shaw, R. K.; Arima, M.; Kagami, H.; Fanning, C. M.; Shiraishi, K.; and Motoyoshi, Y. 1997. Proterozoic events in the Eastern Ghats granulite belt, India: evidence from $\mathrm{Rb}-\mathrm{Sr}$, Sm-Nd systematics and SHRIMP dating. J. Geol. 105:645-656.

Shellnutt, J. G.; Lan, C.; Long, T. V.; Usuki, T.; Yang, H.; Mertzman, S. A.; Iizuka, Y.; Chung, S.; Wang, K.; and Hsu, W. 2013. Formation of Cretaceous cordilleran and post-orogenic granites and their microgranular enclaves from the Dalat zone, southern Vietnam: tectonic implications for the evolution of Southeast Asia. Lithos 182-183:229-241.

Simmat, R., and Raith, M. M. 2008. U-Th-Pb geochronometry of the Eastern Ghats belt, India: timing and spatial disposition of poly-metamorphism. Precambrian Res. 162:16-29.

Srinivasan, K. N., and Roop Kumar, D. 1995. Geological mapping of Podili-Kanigiri section in northern part of Nellore schist belt, Prakasam district, AP. Prog. Rep. Geol. Surv. India FS 1992-1993.

Stacey, J. S., and Kramers J. D. 1975. Approximation of terrestrial lead isotope evolution by a two-stage model. Earth Planet. Sci. Lett. 26:207-221.

Stipp, M.; Stunitz, H.; Heilbronner, P.; and Schmid, S. M. 2002. The eastern Tonale fault zone: a "natural laboratory" for crystal plastic deformation of quartz over a temperature range from 250 to $700^{\circ} \mathrm{C}$. J. Struct. Geol. 24:1861-1884.

Sun, S. S., and McDonough, W. F. 1989. Chemical and isotopic systematics of oceanic basalts: implications for mantle composition and processes. In Saunders, A. D., and Norry, M. J., eds. Magmatism in the ocean basins. Geol. Soc. Lond. Spec. Pub. 42:313-435.

Tripathy, V., and Saha, D. 2010. Structure and low grade metamorphism of the east central part of the Proterozoic Nallamalai fold belt, South India-thrust stacking and discontinuous metamorphic gradients along eastern margin of east Dharwar craton. India J. Geol. 80:173-188.

Upadhyay, D. 2008. Alkaline magmatism along the southeastern margin of the Indian shield: implications for regional geodynamics and constraints on craton-Eastern Ghats belt suturing. Precambrian Res. 162:59-69.

Upadhyay, D.; Raith, M. M.; Mezger, K.; and Hammerschmidt, K. 2006. Mesoproterozoic rift related alkaline magmatism at Elchuru, Prakasam alkaline province, SE India. Lithos 89:447-477.

Venkatakrishna, R., and Dottiwala, F. E. 1987. The Cuddapah salient: a tectonic model for the Cuddapah Basin, India, based on Landsat image interpretation. Tectonophysics 136:237-253.

Vernon, R. H. 2000. Review of microstructural evidence of magmatic and solid-state flow. Electron. Geosci. 5: $1-33$. 
Vijaya Kumar, K.; Ernst, W. G.; Leelanandam, C.; Wooden, J. L.; and Grove, M. J. 2010. First Paleoproterozoic ophiolite from Gondwana: geochronologic-geochemical documentation of ancient oceanic crust from Kandra, SE India. Tectonophysics 487:22-32.

Watson, E. B., and Harrison, T. M. 1983. Zircon saturation revisited: temperature and the composition effects in a variety of crustal magma types. Earth Planet. Sci. Lett. 64:295-304.

Whalen, J. B.; Currie, K. L.; and Chappell, B. W. 1987. A type granites: geochemical characteristic, discrimination and petrogenesis. Contrib. Min. Petrol. 95:407-419.
White, A. J. R. 1979. Sources of granite magmas. Geol. Soc. Am. Abstr. Programs 11:539.

Williams, I. S. 1998. U-Th-Pb geochronology by ion microprobe. In McKibben, M. A.; Shanks, W. C., III; and Ridley, W. I., eds. Reviews of microanalytical techniques to understanding mineralising processes. Rev. Econ. Geol. 7:1-35.

Zibra, I.; Kruhl, J. H.; Montanini, A.; and Tribuzio, R. 2012. Shearing of magma along a high grade shear zone: evolution of microstructures during the transition from magmatic to solid-state flow. J. Struct. Geol. 37:150160 